\title{
perifèria
}

Número 12, juny 2010

www.periferia. name

\section{Xafardera?. No, esclava. Etnografia sobre les porteres de Barcelona}

\author{
J oana Brufau, Carmen Pla i Xavi Zulet ${ }^{1}$ \\ Universitat Autònoma de Barcelona
}

Bestard, Joan (ed.) (2006). Les porteries a Barcelona. Entre l'espai públic i l'espai privat. Barcelona: Generalitat de Catalunya. Departament de Cultura

“Un poco dura esta profesión. Aunque ellos [els veïns] no lo crean, lo es. Siempre hay un mal humor de ellos. Siempre hay alguna cosa, que la paga el trabajador" Testimoni d'una portera recollit en el llibre ${ }^{2}$

La literatura, el cinema i la mateixa realitat han contribuït a generar un dels principals estigmes que giren al voltant de la figura de la portera ${ }^{3}$ : la xafarderia. Per a molta gent, la portera és aquella persona que sap tot el que passa en una comunitat de veïns i que pot fer un ús indegut d'aquesta informació. És la persona que, depèn en quina situació, es millor evitar quan s'entra al bloc de pisos.

L'originalitat de l'obra col-lectiva que ressenyem és que desmunta aquest i d'altres estigmes. Presenta la figura de la portera com a institució fonamental i necessària en la relació entre les categories socials de l'espai públic del carrer i de l'espai privat de la llar familiar, i en dignifica la seva professió. En fa una anàlisi

1) Enviar correspondència a: Joana Brufau jannabrufau@hotmail.com, Carmen Pla cplallorente@yahoo.es, Xavi Zulet xavizulet@gmail.com

$\left.{ }^{2}\right)$ Bestard, Joan (ed.) (2006) Les porteries a Barcelona. Entre l'espai públic i l'espai privat. Barcelona: Generalitat de Catalunya. Departament de Cultura. 226 p. L'obra és el resultat d'una recerca realitzada entre els anys 2002 i 2003 dins el marc de I'Inventari del Patrimoni Etnològic de Catalunya (IPEC) que duu a terme el Centre de Promoció de la Cultura Popular i Tradicional Catalana. És el número 13 de la col·lecció de llibres Temes d'Etnologia de Catalunya.

${ }^{3}$ ) Al llarg de l'obra es fa referència als porters i a les porteres, com a professió que han exercit tant homes com dones. En l'actualitat, la majoria de les persones que ocupen aquest càrrec són dones, és per aquest motiu que en aquesta ressenya ens referirem a aquesta professió en femení. De fet, Josep Maria Carandell afirma que "les porteries barcelonines eren sempre de portera, no de porter". (Bestard, 2006:43) 


\section{perifèria}

Número 12, juny 2010

www.periferia. name

retrospectiva i presenta la lenta construcció de la professió des del segle XIX fins a l'actualitat, moment important de canvis i de desaparició. També descobrirem, però, la situació d'esclavatge a que han estat sotmeses les porteres durant molts anys: disponibilitat total d'horaris i acceptant qualsevol tasca encarregada pels propietaris o llogaters.

Cal entendre aquesta etnografia en el context d'un estudi més ampli ${ }^{4}$ que s'ha realitzat a París, Oslo, Londres, Milan i Barcelona, i que té l'objectiu de comparar la situació dels conserges i les porteres en diverses ciutats europees. L'equip francès de I'IPRAUS (Institut Parisien de Recherche, Architecture, Urbanistique, Societé) n'ha estat l'impulsor inicial. En català o en espanyol hi ha poques referències bibliogràfiques sobre aquesta temàtica des del punt de vista etnogràfic.

Les tècniques d'investigació social usades per l'equip de recerca pluridisciplinar (format per vuit antropòlogues i etnòlogues, dues sociòlogues, una advocada i una arquitecta) ${ }^{5}$ per analitzar la situació de les porteries a Barcelona són diverses. Per obtenir la perspectiva històrica i comprendre l'actualitat s'han utilitzat fonts primàries i fonts secundàries. Pel que fa a les dades primàries s'han consultat diaris del segles XIX i XX, s'han analitzat els textos legislatius que regulen la professió i l'espai, s'han comparat dades estadístiques, s'han realitzat entrevistes (veïns, exporteres, porteres en actiu i conserges), s'ha fet observació participant i s'han analitzat novel-les. Pel que fa a les dades secundàries, s'ha emprat una extensa bibliografia, tant d'assaigs com d'articles de diari i revistes especialitzades. El llenguatge de l'obra és bastant planer i amè, i compta amb la incorporació de cites textuals fetes pels informants, en molts casos, plenes d'ironia.

\footnotetext{
${ }^{4}$ Més informació sobre aquest estudi comparatiu a BONNIN Philippe, VILLANOVA Roselyne de (dir.) (2006). Loges et gardiens; enquêtes en Europe: Paris, Londres, Barcelone, Milan, Oslo. Paris: Creaphis.

${ }^{5}$ El grup que va rebre la beca IPEC formava part del Grup d'Espai Públic del CCCB, i van treballar amb el Grup d'Estudis sobre la Família i Parentiu (GEFP) de la Universitat de Barcelona que dirigeix en Joan Bestard, coordinador d'aquesta recerca i cap del Departament d'Antropologia Social de la UB.
} 


\section{perifèria}

Número 12, juny 2010

www.periferia. name

Pel que fa a l'estructura de l'etnografia hi ha set capítols, uns annexes i una extensa bibliografia. Els continguts estan estructurats en dos eixos diferenciats. Per una banda, es descriu el context històric de la professió i la seva situació actual, i per l'altre, s'indiquen els tipus de porteries que trobem a la ciutat de Barcelona i el seu funcionament. Aquesta anàlisi gira entorn a la idea de que la portera ocupa un lloc privilegiat per a l'observació dels canvis que es produeixen en la modernitat, constituint, les porteries, un reflex del pas del temps i de les dinàmiques culturals que ens afecten.

L'obra ens descriu cóm a mitjans del segle XIX, en el context de l'expansió industrial i urbanística de Barcelona, va aparèixer l'ofici de les porteres, molt vinculat a les tasques de vigilància i de servei domèstic que el precedien. Es vincula l'aparició de les porteries amb l'assentament de cases de veïns de nova planta a l'Eixample i, posteriorment, la seva expansió a zones més populars de la ciutat en relació amb l'arribada de les primeres onades d'immigració a mitjans del segle XX.

La característica principal d'aquestes porteries restava en la confluència en un mateix espai del lloc de treball de la portera, i del seu habitatge, a més de ser l'entrada a l'edifici, ja que sovint s'establia al vestíbul un petit quiosc o un habitatge reduït que comunicava amb aquest mitjançant una porta de vidre o una reixa. Donat que aquest espai de trànsit havia d'esser vigilat durant tota la jornada diürna, el fet de que fos comú a la seva llar permetia a les porteres compaginar aquesta tasca amb feines de caire domèstic o d'altres de remunerades, tot i que això els afectava restant-los intimitat en la seva vida personal.

Ja a les darreries del segle XIX, però sobretot al llarg del segle XX, el valor d'ocupar una porteria residia en l'adquisició d'una feina i d'un habitatge, la qual cosa cobria les necessitats bàsiques d'una població nouvinguda (principalment del sud d'Espanya i de zones rurals de Catalunya) que sustentava l'esperança d'ascendir socialment i d'heretar la porteria, malgrat les precàries condicions en que es trobaven aquestes. 


\section{perifèria}

Número 12, juny 2010

www.periferia. name

Accedir a una porteria suposava assumir el compromís de tenir absoluta disponibilitat horària ( ja que els convenis col-lectius que fixaren la jornada laboral a quaranta hores no es realitzaren fins a la dècada dels vuitanta del segle XX), la qual cosa suposava que la família de la portera estigués molt vinculada a l'activitat de la porteria de manera que solien ser aquests els que la reemplaçaven en cas de malaltia o d'absència.

Les principals ocupacions de les porteres consistien aleshores en el manteniment de l'ordre, la neteja i la vigilància d'aquest espai de trànsit, així com d'altres tasques d'informació i mediació. No obstant això, sovint ocupaven la major part del seu temps amb tasques de caire informal molt vinculades a l'associació de la professió amb l'aspecte servicial dels antics empleats domèstics de les cases burgeses. Per això, es destaca l'ambigüitat del rol assumit tradicionalment per la portera, a mig camí entre les relacions personals i professionals, amb una actitud que pot anar des de l'amistat amb els veïns o propietaris de l'immoble fins a la relació asimètrica i servicial cap aquests.

Aquesta posició híbrida i estratègicament privilegiada fou aprofitada pel poder com a font d'informació i vigilància dels moviments de la població des de pràcticament la seva aparició fins als anys 70 del segle $X X$, inicialment amb les revoltes obreres $i$ després en el context de la guerra civil i de la postguerra. En el context de la dictadura franquista, s'instaurà una política que consistia en collocar com a porters $^{6}$ a membres afins al règim per a premiar-los per al seu servei $i$, d'altra banda, per assegurar-se la lleialtat dels seus informants.

En aquest context de postguerra, hi havia una estreta col-laboració entre partidaris del règim que implicava a porters, serenos, vigilants nocturns, policies locals i alcaldes de barrio. Oficialment aquests eren homes, tot i que a la pràctica sovint eren les dones de la família dels porters les que s'encarregaven de vigilar la porteria. La fi de la dictadura va comportar per als porters la pèrdua de les funcions

\footnotetext{
${ }^{6}$ En aquest cas, les porteries havien de ser ocupades explícitament per "varones de buena conducta, que carezcan de antecedentes penales y no hayan sufrido faltas contra la propiedad, ni de orden público", segons les Reglamentaciones de trabajo de porteros de fincas urbanas de Barcelona, de l'1 de març de 1948 (Bestard, 2006:32).
} 


\section{perifèria}

Número 12, juny 2010

\section{www. periferia.name}

de vigilància i control autoritari, així com la desaparició de les restriccions per accedir a aquests llocs de treball.

La introducció de l'intèrfon als anys seixanta i, una dècada més tard, l'aparició de la figura del conserge, vinculada a la professionalització de l'ofici, comportaren una progressiva devaluació de la feina de porteres, de manera que, cada vegada més s'ha tendit a prescindir dels seus serveis per motius econòmics. Així doncs, les poques porteries en ús que trobem a la ciutat de Barcelona s'ubiquen al casc antic, i en donen testimoni unes dones grans que esperen la jubilació des de l'ínfim espai que ocupen amb l'esperança de que els renovin el contracte de lloguer de la porteria i puguin viure els seus últims dies al mateix lloc on ho han fet al llarg de tota la seva vida.

Els autors d'aquesta etnografia, doncs, fan una exposició clara del procés històric de construcció de la institució de les porteres, i fan una relació, potser excessivament detallada, sobre les tipologies i el funcionament de l'espai físic que ocupen les porteres, és a dir, les porteries. La presència d'una arquitecta en l'equip de recerca, ha permès presentar com són aquests habitacles amb plànols i fotografies. Considerem que l'espai és un element fonamental i moldejador d'aquesta professió, però en el context de l'obra aquest capítol és massa descriptiu.

En el llibre hi ha un capítol en el que els autors fan un recorregut literari sobre la construcció de la institució. Entenem que és un molt bon recurs que ens mostra aspectes complementaris de la vida de les porteres, no obstant, el capítol queda una mica desubicat en el tarannà general de l'obra. Hi ha un trànsit de les dades empíriques i reals obtingudes a través del treball de camp (etnografia), a les dades fictícies i construïdes a partir de l'imaginari col-lectiu (literatura). Tot i això, queda clar que la figura de la portera forma part de la vida urbana dels segles XIX i XX, del món real i del món creatiu. 


\section{perifèria}

Número 12, juny 2010

www. periferia. name

Els conceptes més interessants plantejats en el marc teòric de l'etnografia, són els que estan relacionats amb l'espai públic i l'espai privat, la seva construcció i el seu simbolisme, definint aquests un comportament normatiu i transgressor. Considerem, però, que hi ha un tracte superficial d'alguns elements d'aquest marc de referència, vinculat a algunes dicotomies centrals de la modernitat (públic privat, coneixement - secret, comunitat - contracte, formal - informal i ordre desordre). Les referències als elements centrals d'aquestes dicotomies, semblen un preàmbul d'alguna teoria que vincula les porteres i la modernitat en la que no s'acaba d'aprofundir.

Una lectura global del llibre ens apropa a una visió potser massa nostàlgica i idealitzada de les porteres, com a institució necessària de traspàs entre l'allò públic i l'allò privat. Pensem que els autors dipositen massa responsabilitats en aquesta institució. Consideren que sense la mirada de la portera ara els carrers de la ciutat apareixen més insegurs i anònims. Creuen que cada cop són més necessàries les mediacions simbòliques $i$ pràctiques en els nostres trànsits constants com a ciutadans. Segons ells, les porteres representaven aquesta mediació.

La lectura que en fem nosaltres és que la construcció de l'ofici de portera representa una relació de servilisme amb els propietaris; i un procés de salvació, de fugida i de condemna de la migració del camp a la ciutat, rebutjats per l'ordre dominant de la societat moderna. Hi ha diversos testimonis entrevistats per les investigadores que defineixen la feina de portera com una relació d'esclavatge amb els propietaris.

Considerem que si, com s'ha fet en d'altres països europeus (Anglaterra, França, Suïssa, etc.), es reintrodueix per llei la figura de la portera o del conserge, a fi de lluitar contra la violència urbana o l'esfondrament dels vincles socials, és necessari que hi hagi una regulació que permeti deixar enrere la relació de submissió envers els amos. De fet, els autors de l'estudi dubten que passi el mateix a Barcelona ja que aquesta feina és més pròpia dels barris d'alt standing. De fet, algunes persones entrevistades deien que aquesta figura evoca una altra època, i fins i tot algú explica que li molestava conviure amb un empleat com aquests, i que considerava 


\section{perifèria}

Número 12, juny 2010

www. periferia.name

que eren més propis d'un altre nivell social i que no tenien res a veure amb la zona.

Com hem indicat al principi, aquesta obra forma part d'un estudi comparatiu entre diverses capitals europees fet per diferents grups de recerca. Considerem que hagués sigut interessant que en el llibre es fessin més referències a aquest estudi per saber l'estat de la qüestió en d'altres ciutats. Som conscients, però, que l'objecte d'aquest estudi és fer una etnografia de les porteries a Barcelona, i que per aquest motiu es fa difícil incorporar aquesta perspectiva comparativa antropològica.

Un altre aspecte que considerem que hagués estat positiu és que el capítol final de les conclusions fos una mica més extens, incorporant les diferents perspectives treballades en el llibre i indicant aquelles teories que en algun moment del llibre s'apunten però en les que no s'aprofundeix prou.

Voldríem acabar aquesta ressenya recomanant la lectura d'aquesta etnografia a aquelles persones que vulguin conèixer de prop una realitat urbana tant propera, que fa referència a una institució que sovint se'ns presenta invisible i humil, i que ocupa aquell espai interior que sovint veiem de passada als interiors dels edificis dels carrers de les grans ciutats. És una lectura agradable i amena que sorprèn en determinats aspectes descriptius i funcionals de les porteres. Podrem entendre, entre d'altres coses, el perquè i el com s'ha construït l'estigma de la portera com a xafardera, quina era la relació d'esclavatge amb els propietaris, el caràcter hereditari familiar de l'ofici i l'extrema diplomàcia i mà esquerra que havien de tenir per tractar a cada una de les individualitats del seu edifici.

\section{Bibliografia}

Delgado Ruíz, M. (2002). Disoluciones urbanas; procesos identitarios y espacio público. Antioquia: Editorial Universidad de Antioquia. 